Buychik, A., Tomanek, A. (2020). The influence of postmodernism on the evolution of art in the 21 st century. 21 st century: history and modernity of art. Collection of Scientific Articles. European Scientific e-Journal, 4 (4), 43-53. HlučínBobrovníky: "Anisiia Tomanek" OSVČ.

Buychik, A., Tomanek, A. (2020). Vliv postmodernismu na vývoj umění v 21 století. 21 st century: history and modernity of art. Collection of Scientific Articles. European Scientific e-Journal, 4 (4), 43-53. Hlučín-Bobrovníky: "Anisiia Tomanek" OSVČ.

DOI: $10.47451 / \operatorname{art} 2020-12-005$

EOI: $10.11244 / \operatorname{art} 2021-12-005$

The paper is published in Crossref, Internet Archive, Google Scholar, Academic Resource Index ResearchBib, JGate, ISI, CiteFactor, ICI, eLibrary databases.

\section{Alexander Buychik Doctor of Economical Sciences, PhD of Social Sciences Chief Director European Scientific e-Journal Ostrava-Hlučín, Czech Republic E-mail: info@buychik.eu}

Anisiia Tomanek Master of Social Sciences and Cultural Studies

Executive Director European Scientific e-Journal Ostrava-Hlučín, Czech Republic E-mail: ex@tuculart.eu

\title{
The influence of postmodernism on the evolution of art in the 21st century
}

\section{Abstract:}

In the modern world, a person is surrounded by an endless stream of data, which is often difficult to control. However, whether explicitly or implicitly, this flow has an impact on us: through advertising images, products in stores, the Internet and television. So, this leaves a huge imprint on our worldview and perception of the world not only at the everyday level but also at the level of perception of modern art. The article provides a comparative analysis of the influence of postmodernism ideas and philosophy on the transformation of the 21st century art from the point of view of the formation of positive and negative trends in the development of modern art. The authors conclude that postmodernism, combined with changes in global politics aimed at constant information pressure and depersonalization of the individual, so transforms art that its latest forms and trends can destroy the very classical concept of art, which is designed to reflect the individualism and versatility of man. Technological evolution as a result of the philosophy of postmodernism is ready both to develop art at a new level and to destroy its purpose.

Keywords:

postmodernism, art, transformation, evolution, Nietzsche, Groys, Heidegger, Krauss, Benhabib. 
Generální ředitel

European Scientific e-Journal Ostrava-Hlučín, Czech Republic

E-mail: info@buychik.eu

Anisiia Tomanek

Magistr sociálních a kulturních věd

Výkonný ředitel

European Scientific e-Journal

Ostrava-Hlučín, Czech Republic

E-mail: ex@tuculart.eu

\section{Vliv postmodernismu na vývoj umění v 21 století}

Anotace:

V dnešním světě člověka obklopuje nekonečný proud dat, který je často obtížné kontrolovat. Nicméně, explicitně nebo implicitně, tento proud nás ovlivňuje: prostřednictvím reklamních obrázků, zboží v obchodech, internetu a televize. To tedy prínáší obrovský otisk našeho pohledu na svět a vnímání světa nejen na domácí úrovni, ale i na úrovni vnímání současného umění. V článku je provedena srovnávací analýza vlivu idejí a filozofie postmodernismu na transformaci umění 21 století z hlediska formování pozitivních a negativních trendů ve vývoji moderního umění. Autoři $\mathrm{k}$ závěru, že postmodernismus se $\mathrm{v}$ kombinaci se změnami ve světové politice, zaměřeným na trvalé informační tlak a обезмичивание osobnosti, tak transformuje umění, že jeho nejnovější formy a trendy, které mohou zničit samotnou klasickou koncepci umění, která si klade za cíl odrážet individualismus a mnohostrannost člověka. Technologický vývoj $\mathrm{v}$ důsledku filozofie postmodernismu je připraven jak rozvíjet umění na nové úrovni, tak zničit jeho účel.

Klićové slova:

postmodernismus, umění, transformace, evoluce, Nietzsche, Groys, Heidegger, Krauss, Benhabib.

\section{Introduction}

In the modern world, a person is surrounded by an endless stream of data, which is often difficult to control. However, whether explicitly or implicitly, this flow has an impact on us: through advertising images, products in stores, the Internet and television. So, this leaves a huge imprint on our worldview and perception of the world not only at the everyday level but also at the level of perception of modern art.

Post-modern art undoubtedly leads to a dialogue with the viewer. However, at a certain stage, there may be a lack of understanding of the meanings or rejection of the forms of modern art objects. Immediately follows a negative reaction: denial or rejection. It is at this point that the problem arises: how to interpret what the viewer has just seen.

Consequently, there is a need to rethink postmodernism as the basis for the transformation of art in the late 20th and early 21 st centuries. The relevance of understanding is also generated by the question of the opposite views on modern art of 
the 21st century, a deep criticism of modern and ultramodern trends in painting, sculpture, graphics and other areas.

Postmodernism is the period in art that followed the dominance of modernism in the theory and practice of culture. This trend, which arose in the middle of the 20th century, ideologically united many contemporary artists. It is directly connected with scepticism, irony, and philosophical criticism of universal truths and objective reality. The very term "postmodernism" was introduced into use by Jean-François Lyotard in his work "The Postmodern Condition" (1979), in which the idea of a "language game" was played out. Proposed by the Austrian Ludwig Wittgenstein, the idea was that different groups of people use the same language in different ways - and this, in turn, can lead to the fact that they will look at the world in completely different ways (Post-Modernism, 2014).

Postmodern art is a body of art movements that sought to contradict some aspects of modernism or some aspects that emerged or developed in its aftermath. In general, movements such as intermedia, installation art, conceptual art and multimedia, particularly involving video are described as postmodern. There are several characteristics which lend art to being postmodern; these include bricolage, the use of text prominently as the central artistic element, collage, simplification, appropriation, performance art, the recycling of past styles and themes in a modern-day context, as well as the break-up of the barrier between fine and high arts and low art and popular culture (Bertens, 1997).

Postmodernism describes movements which both arise from, and react against or reject, trends in modernism (Krauss, 1986). General citations for specific trends of modernism are formal purity, medium specificity, art for art's sake, authenticity, universality, originality and revolutionary or reactionary tendency, i.e., the avant-garde. However, the paradox is probably the most important modernist idea against which postmodernism reacts. The paradox was central to the modernist enterprise, which Manet introduced. Manet's various violations of representational art brought to prominence the supposed mutual exclusiveness of reality and representation, design and representation, abstraction and reality, and so on. The incorporation of paradox was highly stimulating from Manet to the conceptualists.

The status of the avant-garde is controversial: many institutions argue being visionary, forward-looking, cutting-edge, and progressive are crucial to the mission of art in the present, and therefore postmodern art contradicts the value of "art of our times". Postmodernism rejects the notion of advancement or progress in art per se, and thus aims to overturn the "myth of the avant-garde". Rosalind Krauss was one of the important enunciators of the view that avant-gardism was over, and the new artistic era is post-liberal and post-progress (Krauss, 1986). Griselda Pollock studied and confronted the avantgarde and modern art in a series of groundbreaking books, reviewing modern art at the same time as redefining postmodern art (Pollock, 1999). 
The depth of the subject comprehension and the metaphysics of the modernist artists were contrasted by superficiality, irony and the gesture art. Postmodernism allowed artists to criticize everyone and everything, destroy the old foundations of painting, deny the tastes of the public. Neo-Dada and pop art appeared in post-war America, and over the next several decades, reactionary art forms called to live such trends as minimalism, conceptual art, performance art, and video art (Pegrum, 2000). All of these movements of postmodernism, diverse in their essence and form, have common characteristics, such as a mixture of hierarchies of high and low art, a rejection of the concepts of authenticity and originality that are characteristic of modernists, emphasizing entertainment, irony and playfulness (Post-Modernism, 2014).

Thus, it should be said that Postmodernism plays a fundamental role in the formation of the art of the 21st century as an Era of Art Rebellion, which changed the philosophy of new generations given unique freedom of thoughts to reform classic of Modernism. Totally, humanity has come to digital technologies, which transformed all kinds of art.

\section{Philosophical understanding of postmodernism}

A distinctive feature of postmodernism is the belief that it is impossible to explain the structure of the world as something full-fledged, developing according to certain laws and available for theoretical study.

Another feature of postmodernism is its innovative orientation. Representatives of postmodernism believe that it is an important stage in the development of European culture, the period of late capitalism, and post-industrial society. This is due to the emergence of the postmodern era in developed countries in the second half of the 1960s, that is, the rapid transition from an industrial society to an information one. It is then that the latest electronic technologies begin to develop, which formed the basis of postmodern culture.

The pathos of innovation and radical anti-traditionalism of postmodernism is explained by the fact that even at the very beginning of the world postmodern movement in the 20th century, the idea was repeatedly expressed that the current stage is fundamentally different from everything that history has previously known. The modern culture was conceived not as a new phase of evolution, but as something unique, incomparable. Postmodernism has further intensified and sharpened this radicalism, as a result of which the characterization of modern reality as a 'post-culture' has become widespread.

For postmodernism, the Nietzsche treatise On Truth and Lie in an Extra-Moral Sense (Clark, 1990) where he introduces a systematic collection of philosophical concepts is important. In this text, the philosopher hypothesizes that scientific concepts are chains of metaphors frozen in generally accepted truths. Nietzsche believed that reality is not an 
ordered, objective and law-like entity, but a continuous stream of being in the process of becoming. Man is not able to know it, and those laws that help to describe cause-andeffect relationships in the world are nothing more than a fiction, always aimed at the sphere of practical interests (Kaufmann, 1974).

Heidegger continued Nietzsche's line, focusing his attention on the study of reason, which eventually degenerates into reason. Such thinking was considered by the philosopher to be 'calculative', the highest form of which is the technique that develops against humanism. Humanism, Heidegger believed, invariably becomes barbarism, in which "the deserts caused by technology multiply". Heidegger, like Nietzsche, proceeded from the negation of the ideal, the other world, that is, from the understanding of reality as being. He also recognized the unity of mind and body, noting that it is the biological and the animal, not the rational, that is the foundation of this unity. Heidegger believed that although a person is free, he is 'thrown' into the world, forced to balance between free will and external circumstances. Man, in his understanding, is not the centre of the world, he is a participant in being, which is 'revealed' to him (Heidegger, 1991).

The postmodern direction of philosophy is based on the principles of pluralism and relativism, according to which in reality a "plurality of orders" is postulated, which is not subject to hierarchical systematization. pluralism is the main distinguishing feature of the philosophical movement. it allows for the simultaneous coexistence of various points of view. the principle of pluralism is fundamental for understanding postmodernism and its impact on the identity of a postmodern person. Relativism in postmodernism is a philosophical doctrine that asserts that all knowledge is relative and there is no absolute truth, but only truths that a particular person or culture believes in. Postmodernism holds that any knowledge and values are relative and conditioned by the situation. The denial of absolute truth or absolute values is manifested in the philosophical current by the denial of "big narratives" ("great projects"), distrust of any ideologies; postmodernism calls everything into question (McGowan, 1991).

In contrast to traditional ontology, the real basis of the world postmodernists recognizes multiplicity, radical diversity, and in a particularly free, unfettered form of 'chaos'. The world for postmodernists is not a whole, but a set of fragments, between which connections are not always established. To characterize this position, there is a category of 'rhizome', which treats the way of being wholeness as fundamentally nonstructural. Multiplicity and randomness for representatives of the current is a synonym for vitality, sure evidence of authenticity, non-confusion. Unity is associated with forced averaging, levelling differences, rationalistic reduction to a "common denominator".

From the point of view of postmodernism, the search for the real and true does not make sense. The specificity of the current lies in the denial of the possibility of rational explanation and transformation of society. Postmodernism declares that there is not and 
cannot be a transcendental (i.e., transcending sense experience) mind; what people call reason or reason is only an effect of discourse. postmodernists believe that there are no immediate or indisputable characteristics of the life of consciousness. Sensations, ideas, concepts and perceptions arise in the environment of various discursive practices and reflect them.

Postmodernism criticizes the belief in objectivity, which becomes a myth for it. However, without a meaningful goal and perspective, it is impossible to build arguments, interpret events, and even just collect data, so the similarity of objectivity, its replacement in postmodernism, is intersubjectivity, that is, a set of interpretations, points of view that give the most objective picture as possible.

From the point of view of postmodernism, the rationalism of the modern era is bringing to the extreme the idea of the transformative activity of the subject, which entered into an irreconcilable conflict with nature, artificially limited its evolution, as well as the history of society, the space of human freedom. Rationality, from the point of view of postmodernists, is opposed to the idea of humanity, that is, the priority of humanism, the use of all resources to make people's lives as comfortable and safe as possible. The absolutization of rationalism contributes to the dehumanization of the individual and is a source of global dangers, risks, and threats to humanity. Postmodernism points to a variety of types of rationalism, ignoring their natural existence. this diversity does exist, but it appears to be qualitatively different connections due to the transition of human consciousness from one state to another. Postmodernists ignore the historical development of culture as successive types of rationality.

Thus, postmodernism served as the basis of rebellious thinking, which society interpreted as an innovative vision of what exists around. Denial was the reason for the change. The new need for change gave rise to a rethinking of being. Reinterpretation transformed art by bringing in new technical developments that transformed many areas of art and created new directions.

\section{Transformation of art in the 21st century}

Creativity is beyond the control not only of society but also of the artist himself. The gaze of the Other is constantly directed at him, who seeks not so much to learn the secrets as to recognize their difference, to reduce everything to what is visible to the eye. However, with the advent of the Internet, the situation changes, since now the artist appears not as a constructed subject, a character, but as a real person with certain interests, desires and needs. Thanks to this, the works also acquire a dual nature: the profane, caused by the presence of the creator, will join the initially artistic one. It is the emergence of the Internet that deprives the artist of the status of an extraordinary person. Today, no one is not involved in artistic activities through virtual space. Therefore, the main criterion of the 
peculiarity now is not the difference from others, but from the ability to refuse identification, and therefore from themselves. Characteristics do not indicate the internal content, but only the definition by others. So, this is no longer a question of truth, but of power: who has the right to my identity, me or social institutions? According to Groys "The politics of contemporary art is the politics of non-identity" (Groys, 1992) The artist tells the viewer that he is not the image that can be constructed when looking at the work. and it is thanks to the internet that the artist can go beyond the prescribed context.

The main dramatic moments in human nature are largely aggravated in the $21 \mathrm{st}$ century. With the growing influence of atheism, people find themselves alone, but at the same time surrounded by other people. The saturation of the information field gives rise to a sense of the insignificance of man in the world. The great God who was the foundation of spirituality in the previous era is disappearing. However, it is replaced by Another in the postmodern sense. It is other people who are the restraints of freedom, an obstacle to the fulfilment of their desires. One of the situations that arise as a consequence is described by G. Bataille in his book Literature and Evil (Bataille, 1973). However, despite its reference, first of all, to literature, this concept can be applied to any field of art. for him, the difference between humans and animals is in the ability to break prohibitions. a challenge to existing norms and mores is understood as an opportunity for work to take place. The creator is guilty in advance because he contradicts the laws of society. What is this confrontation? literature belongs to the realm of evil, not in the sense of the absence of morality, but the proclamation of super-morality. Such Evil does not think about profit, it is aimed exclusively at the present and at obtaining pleasure. Good is focused on profit, on well-being, in the future. It is the act of creativity that allows you to get pleasure but at the cost of breaking with reality. Conventional morality is challenged since its conventional attitudes are always lower than personal super-morality. The value of impulse is opposed to reason. Of course, modern art at its best is just such an Evil. The artist always belongs to the world of childhood and sees the falsity in the life of society that unfolds around him.

Art is one of the many communication systems inherent in a person, which makes it related to natural language. the most important thing in understanding a language is to avoid understanding it as code that accurately conveys information. In reality, a language is a complex form of interaction, which implies a connection between the meaning of the speaker (the created work) and the system of understanding of the recipient. Speaking about the importance of language in the process of understanding and interaction, it is important to avoid the trap that poststructuralism is primarily responsible for creating. It consists in the fact that the metaphysical idea of the existence of a transcendental foundation has been replaced by the interpretation of human existence as built on language, text, and communicative practices. The situation in which contemporary art is 
located largely demonstrates the mechanism of action of this trap. Art, as mentioned above, fell silent. However, the works must still be presented to the audience. So, the result of this was the close dependence of the work of art and text framing in modern practice. Boris Groys writes that art has become a commentary on art. The text becomes a kind of clothing that presents art to the viewer. This framing of the unspoken into words should relieve tension, make the perception more pleasant and understandable for the viewer. Therefore, in the modern system of exhibiting art, the critic becomes one of the most important elements. However, its function is fundamentally different than it was during the existence of classical art forms. Then the critic spoke on the side of the public, talking about the value or lack of it in a particular work. now he is on the side of the artistic environment. however, this leads to an even greater confrontation between the critic and the artist. the artist believes that the text scares the viewer away from the work, hides and blurs its true content. therefore, often, the artist himself becomes a critic, trying to fill the void between the work and the viewer through the text. but in the absence of uniform aesthetic criteria, the public does not trust critics whose point of view is subjective. but he does not trust his taste, so he does not have an unambiguous basis for its formation (Groys, 1992).

Like sociality itself, art is now discursive. Production in it does not depend on any structures (such as art institutions), but primarily on direct relations in society. It does not have a centre that was associated with the dominant direction, school, or dominant region. In the absence of clear criteria, no framework would allow us to say whether the work belongs to art or any other field. It exists precisely in its openness and variability.

Theories of multiculturalism are becoming very important for understanding all spheres of human life in the realities of globalization. In his works, S. Benhabib questions the universalist or, on the contrary, relativistic views on the culture that prevailed in philosophical circles. It puts forward the idea of a complex interpenetration of cultures, both among themselves and within each cultural area or individual. Her thoughts are also transferred to contemporary art. Just as it is not necessary to use some universalist statements about the general nature or possibilities of the same cognitive research in reasoning about man, so it is also necessary to use art. It can no longer be said that all artists are trying to bring a single meaning since the field of their ideas is very large and is not limited to a single cultural or aesthetic tradition (Benhabib, 2002).

Like cultures in a global world subject to constant interaction, the types and genres of art no longer exist on their own. pure genres are disappearing, as are pure languages and nations, which are now more of an imaginary construct. This diversity reflects a changed view of a difference that is no longer considered marginal, needing to be clearly defined or isolated. Finally, concerning contemporary art, as concerning phenomena belonging to other cultures, the main thing is interaction. People are very multi-faceted in 
their perception, as a rule, their result of interaction with something else does not belong to the extreme of full acceptance, nor the extreme of the desire for destruction inherent in mainly totalitarian cultures. The basis of multidimensional dialogue primarily is the ability of a person to change. Therefore, the beginning of understanding the works of modern art, as well as any unknown phenomena belonging to other cultures, primarily is the rejection of categorical judgments that put themselves in opposition to the other. Since due to the lack of integrity of the cultural field and the identity of a person, in any seemingly different one can find a correspondence to the familiar. Fundamental untranslatability, within the framework of such an understanding, is considered an illusion, since the very fact of judgments about another culture or new trends in art already indicates their identification and acceptance (Kutlunina, 2018).

Thus, postmodernism, combined with changes in global politics aimed at constant information pressure and depersonalization of the individual, so transforms art that its latest forms and trends can destroy the very classical concept of art, which is designed to reflect the individualism and versatility of man. Technological evolution as a result of the philosophy of postmodernism is ready both to develop art at a new level and to destroy its purpose.

\section{Conclusion}

In conclusion, it should be noted that postmodernism has played a significant role in shaping the art of the 21st century. The philosophy of negation of the existing and need to create a new one gave rise not only to pop culture of the second half of the 20th century but also contributed to the formation of fundamentally new thinking in art, i.e., the thinking of constant innovation and the insufficiency of what has been achieved.

At the initial stage of transformation, art received a new qualitative push, which gave rise to new types that actively used the achievements of science and technology computer graphics, 3D modelling, holography, the use of new materials, the development of new technologies and techniques. The person was able to realize their ideas in the most realistic form.

However, it should also be noted that at the next stage of transformation, art faced a relatively rapid achievement of certain limits of the use of technology, while maintaining the need for postmodernism in constant improvement and evolution, denying the relevance of the existing one. What was created at the initial stage gradually becomes 'classic' for postmodernism. Consequently, the transformation begins to go deeper and deeper into itself already in an unmanageable trend, which gives rise to a conflict of vision and values of art, which is amplified. 


\section{References:}

Bataille, G.A. (1973). Literature and Evil. Alastair Hamilton, Calder \& Boyars Ltd.

Benhabib, S. (2002). The Claims of Culture. Princeton University Press.

Bertens, H. (1997). International postmodernism: theory and literary practice. Routledge.

Clark, M. (1990). Nietzsche on Truth and Philosophy. Cambridge: Cambridge University Press. Groys, B. (1992). The total art of Stalinism: avant-garde, aesthetic dictatorship, and beyond. Princeton, N.J.; Oxford, Princeton University Press.

Heidegger, M. (1991). Nietzsche. Translated by Davis Farrell Krell. Harper San Francisco, Harper Collins.

Kaufmann, W. (1974). Nietzsche: Philosopher, Psychologist, Antichrist. Princeton University Press.

Krauss, Rosalind E. (1986). The Originality of the Avant Garde and Other Modernist Myths. Part I. Modernist Myths. The MIT Press.

Kutlunina, E.V. (2018). The problem of understanding contemporary art. New Ideas in Philosophy: Materials of the 4th International Scientific Conference (St Petersburg, July 2018), 14-20. St Petersburg: Svoe Izdatelstvo.

McGowan, John P. (1991). Postmodernism and its Critics. Cornell University Press.

Pegrum, Mark A. (2000). Challenging Modernity: Dada Between Modern and Postmodern. Berghahn Books.

Pollock, G. (1999). Differencing the Canon. London \& N.Y.: Routledge.

Post-Modernism (2014). Retrieved October 12, 2020 from https://artchive.ru/en/styles/postmodernism 